\title{
The Importance of Chinese Cultural Infiltration in College English Teaching and Its Implementation
}

\author{
Xue $\mathrm{Li}^{*}$ \\ School of Foreign Languages, Dalian Jiaotong University, Dalian, Liaoning 116028, China \\ *Corresponding author. Email: lixue_sherry@djtu.edu.cn
}

\begin{abstract}
With the in-depth development of economic globalization, economic and cultural exchanges between countries have become more and more frequent. In our country, the status of culture and education in college English teaching has been paid more and more attention. However, college English teaching has been ignoring the infiltration of Chinese culture and only unilaterally absorbing western culture, which has produced many bad effects. By analyzing the problems existing in cultural input, the author discusses the importance of strengthening Chinese cultural infiltration in college English teaching, and seeks for effective ways to implement teaching methods. In this way, we can change current situation of our own cultural aphasia in English teaching, improve people's understanding of our own culture and sense of pride, and use English as a medium to spread Chinese culture to the outside world.
\end{abstract}

Keywords: Chinese culture, college English teaching, importance, culture infiltration, implementation

\section{INTRODUCTION}

Culture is mainly a complex of different forms of social production mode, life mode, thinking mode, speech mode, values, ethics and other behavior mode. Language teaching is closely related to cultural teaching. Culture embraces and influences language; Language is the carrier of culture, an important part of culture, and an indispensable tool to preserve, communicate and reflect culture. Language develops with the development of a nation.

Marshall Mcluhan [1] predicted in the 1960s that the world would become a global village, and now it has been confirmed. With the development of information and communication technology, people and countries all over the world are connected with each other. Therefore, the culture reflected by English should not only be limited to the culture of British and American countries, but also reflect the culture of various countries in the world.

In a long period of time, foreign language teaching in China is only limited to the cultivation of language ability, and cultural teaching has become a dispensable ornament. However, in real life, when our students really communicate with foreigners, they find that although their English grammar and semantics are correct, they cannot carry out effective cross-cultural communication because of improper language use and violation of cultural rules [2]. This phenomenon forces many scholars to combine the teaching of language and culture in classroom practice. Therefore, the goal of foreign language teaching has gradually gone beyond merely cultivating students' listening, speaking, reading and writing abilities, and has gradually taken the cultivation of students' intercultural consciousness and intercultural communication ability as an English teaching goal in a new era.

\section{PROBLEMS EXISTING IN THE PROCESS OF CHINESE CULTURE INFILTRATION}

\subsection{Ignorance of the Importance and Necessity of Culture Infiltration in College English Teaching}

According to our country "college English curriculum requirements" [3], the teaching aim of college English is to cultivate students English comprehensive application ability, especially listening and speaking skills, making them use English effectively both in written and spoken communication in the future work and social interactions. At the same time we should improve students' ability of autonomous learning and improve their comprehensive cultural quality to adapt to the needs of economic development and international exchange in our country. This means that the English teaching education workers should not only teach students the basic knowledge of pragmatics, but also target the language countries, local conditions and customs, culture and historical background and cultural knowledge.

However, cultural teaching in China is chaotic at present. For example, teachers are random and arbitrary in teaching methods, while students only learn languages based on their own interests and interests. At the same time, from the point of view of teachers themselves, some teachers' cultural literacy needs to be improved. Affected by the traditional teaching mode, part of teachers' classroom teaching is to teach fundamental cognitive language 
knowledge. In the process of teaching, teachers cannot give equal attention to language knowledge and cultural knowledge, thus neglecting the cultivation of students' cultural consciousness, which will affect the talent cultivating cross-cultural communication ability plans and implementation.

\subsection{Cultural Input Imbalance Exists in The Process of Cultural Teaching}

Because our country university curriculum and teaching material test content did not highlight the cultivation of the ability to express Chinese culture in English, many education workers and students agree that English language teaching should be the target language culture teaching of the single culture teaching and learning, and caused some serious lack of teachers and students' mother tongue culture. Therefore, for a long time, the introduction of British and American culture and spread has been part of cultural teaching in English teaching and occupied a dominant position. Many college English teachers only pay attention to culture teaching in class to teach English native language culture and custom of the country, and regardless of Chinese cultural essence and the background of grant.

As we all know, the reason why English has the largest number of second foreign language learners in the world is mainly due to its uniqueness as the common language and means of international communication [4]. At present, all countries in the world have diversified communication characteristics, and any communication is not a single communication between two countries. Therefore, we should not only understand the customs of other countries in the communication, at the same time, we have the obligation and responsibility to make each other understand and finally recognize and respect our culture, etiquette and customs. However, cultural teaching in college English teaching in China, especially the teaching of Chinese culture, has not yet formed a unified system. Most of the series of textbooks used are about the introduction of the social and cultural background knowledge of English-speaking countries, while the content about the introduction and dissemination of Chinese traditional culture is almost zero. If we, as knowledge disseminators, only pay attention to the input of such a single cultural teaching in the classroom, it will eventually result in the loss of our country's long-standing culture and civilized etiquette, and at the same time, it will inevitably lead to the lack of necessary knowledge reserve ability in cultivating talents with intercultural communication skills.

\section{THE IMPORTANCE AND NECESSITY OF STRENGTHENING THE INFILTRATION OF CHINESE CULTURE INTO COLLEGE ENGLISH TEACHING}

\subsection{Mother Tongue has a Positive Transfer Effect on Second Language Learning}

Transfer is a psychological term that refers to the influence of one kind of learning on another. Robert Lado [5], an American linguist, first proposed "language transfer" in the 1950s. Language Transfer can be divided into Positive Transfer and Negative Transfer. Positive transfer means that language learners transfer the previously acquired knowledge in their mother tongue to the second language learning, and this transfer will promote the second language learning. Negative transfer impedes second language learning. According to the second language acquisition theory, mother tongue and mother tongue culture have a definite positive transfer effect on English learning and communicative competence. Mother tongue is the cognitive basis of second language learning, and the process of foreign language learning is the process of information processing. In the process of second language learning, learners have to rely on their mother tongue for cognitive processing.

College students in China basically grow up and learn in the environment of their mother tongue. Before learning the second language, they have formed a set of nativebased learning rules, which will be applied to the second language learning before they have fully mastered the second language. It is a normal learning process for learners to learn a second language by using the learning rules of their mother tongue. If the mother tongue is eliminated in the process of learning a second language, it is not in accordance with the rules of language learning [6]. Therefore, in college English teaching, teachers should appropriately compare the target language with the mother tongue and the culture of the target language with the culture of the mother tongue, so that students can have a deeper understanding of the similarities and differences between the target language and the mother tongue, so as to better promote the study of the target language.

\subsection{The Infiltration of Chinese Culture Improves Students' Ability to Distinguish Cultural Differences}

College students are in the process of forming their values and ways of thinking. They have a strong curiosity for new things and strong learning ability, but they still lack the ability to distinguish things. Therefore, English teachers should dialectically teach Chinese and western cultures in the process of second language teaching, and treat target language culture and native language culture equally and fairly in the process of cultural teaching, so as to 
encourage students to develop critical cultural awareness and improve the ability to distinguish cultural differences. When learning and absorbing western culture, we should use critical thinking to dialectically study the culture of target language and mother tongue. We should adopt the attitude of "taking the essence and discarding the dross". We should not blindly believe that western culture is superior to Chinese traditional culture, and then worship foreign things. Also, we should not to take the attitude of exclusion, refused to all western foreign culture. In the process of college English teaching, teachers should input Chinese culture appropriately and guide students to learn the essence of western culture correctly, so as to protect the fine traditions of Chinese culture.

\subsection{The Infiltration of Chinese Culture has an Effective Way on Cultivating Students' Humanistic Quality and Shaping Their Personality}

The cultivation of students in schools includes two aspects: on the one hand, students' scientific knowledge is cultivated through knowledge imparting; on the other hand, students' humanistic quality is cultivated to help students establish a correct outlook on life and values. These two aspects are equally important. Humanistic quality is the core of humanistic spirit, is "the pursuit of the value of a man", namely through faith, ideal of human thinking and behaviour, value orientation, aesthetic feeling boring, etc [7]. Language and culture are closely related, language is the carrier of culture, and culture is the intrinsic essence of language, both of which cannot exist alone. In the process of language teaching, cultural education is very important and indispensable. The period of university is an important stage of students' physical and mental development and personality shaping. Schools and teachers shoulder the important tasks of spreading knowledge, personality shaping and sound. English language teaching is not only limited to the impartation of English language knowledge and language skills, but should be sublimated to the cultivation of human factors. In English teaching, teachers should adopt a contrastive teaching method of Chinese and foreign cultures, infiltrate the native language culture and western culture into classroom teaching activities at the same time, improve students' cultural sensitivity, improve students' innovative thinking ability, and promote the formation of students' attitude to tolerate foreign cultures and carry forward native language culture.

\subsection{The Infiltration of Chinese Culture is the Basis for Realizing Cross-cultural Communication}

Intercultural communication refers to the communicative behavior of people with different cultural backgrounds, lifestyles and habits of thinking [8]. Cross-cultural communication has two indispensable elements: local culture and target language culture. Communication refers to the cultural exchange between the two sides of the communication. On the basis of understanding and absorbing the culture of the target language, the two sides spread the local culture to the communicating object, instead of simply understanding the culture of the target language. Mr. Wang zongyan pointed out that "crosscultural communication is the communication between two parties, rather than learning from one side unilaterally." With the development of China's economy, cross-cultural communication is deepening. In the process of second language teaching, the Chinese and western cultures keep coming into our life, while the mother tongue, as the premise of cross-cultural communication, is ignored.

In cross-cultural communication, we are familiar with the cultural knowledge of the target language, but we cannot spread the excellent traditional Chinese cultural knowledge. In cross-cultural communication, the mother tongue culture is the premise of communication. Without mother tongue culture, there would be no cross-cultural communication. The purpose of cross-cultural communication is to spread, inherit and develop the mother tongue culture. Language and culture are a kind of status symbol. If only the target language culture is involved in the communication but the mother tongue culture is ignored, then the identity symbol and status will be lost.

\section{IMPLEMENTION OF CHINESE CULTURAL EDUCATION IN COLLEGE ENGLISH TEACHING}

\subsection{Appropriately Increase the Proportion of Chinese Culture in Textbooks}

At present, there is a lack of textbooks about Chinese culture in college English teaching in China, so the crosscultural communication in China is only a theoretical discussion [9]. Because there is no systematic teaching materials, students cannot get a good training in this field, which often leads to students' understanding of the culture of English-speaking countries, but have no in-depth understanding of their own culture. Therefore, there is an urgent need for China to add some content comparing Chinese culture with the culture of English-speaking countries in college English textbooks. Language and culture are inseparable, and students should not only learn the culture of English-speaking countries, but also deepen their understanding of their own culture. Here, we suggest that the compilation of college English teaching materials should not only focus on the basic teaching contents of listening, speaking, reading, writing and translating, but also include some excellent English articles that can reflect Chinese culture into the teaching materials, so as to 
improve the students' ability to apply and express their own culture while learning English.

\subsection{Add Chinese Culture Teaching to College English Classroom Teaching}

College English syllabus widely opened the English national culture introduction class, such as British and American national culture present situation, but the Chinese native culture basic did not open, students are from beginning to end all contact with the culture of English countries, over time, students lack influence on Chinese traditional culture, is not conducive to the longterm development of the Chinese culture. Therefore, we should add more English courses about Chinese culture (including philosophy, history, religion, literature and art, etc.) to the college English curriculum. This process is slow, but it is really a must. This change in the course setting not only introduces Chinese culture to students, but also improves students' ability to use English.

\subsection{Improve Teachers' Own Cultural Quality and Awareness}

With the increasing demand on the ability to use English, English teachers should not only undertake language teaching, but also undertake the important task of spreading Chinese culture. To penetrate Chinese culture in college English teaching requires teachers not only to have a good language foundation, but also to have a deep understanding of Chinese culture. The high or low cultural quality of teachers will have a great impact on English teaching. Teachers should constantly improve their own cultural quality, read in a planned way for teaching, especially English books and magazines about Chinese culture, and accumulate knowledge about mother tongue culture. Only in this way can teachers adapt to the development of modern English teaching.

\subsection{Infiltrate Chinese Culture in Extracurricular Activities}

Classroom teaching time is very limited, so it is necessary to include knowledge of Chinese culture in extracurricular activities. For example, an English speech contest with the theme of Chinese native culture can be held to help students learn about Chinese native culture by themselves, deepen their understanding of local culture, and enhance their national pride and cultural self-confidence. In addition, the English corner can also be used to make students fully feel the authenticity and life of mother tongue culture, so as to create a real and relaxing learning environment for students. English lectures are also a good way to learn Chinese culture, so that students can receive systematic education of traditional Chinese culture from experts and scholars who are proficient in local Chinese culture.

\section{CONCLUSION}

In college English teaching, proper integration of local culture and dialectical absorption of the essence of Chinese and western culture is the need of cross-cultural communication, as well as the need of dissemination, inheritance and innovation of local culture. The key to the teaching of traditional culture in college English teaching is to cultivate cross-cultural mediators, who have multiple identities and can avoid ignoring non-national cultures because of a single identity. They will not unilaterally absorb foreign cultures and cannot spread Chinese culture to the outside world. The relationship between language and culture determines that language knowledge and cultural input are equally important in college English teaching. However, when we choose cultural input content, we should be targeted and purposeful. Cultural input must be closely combined with language teaching to achieve the effect of complementation, so as to better train qualified talents with intercultural communication skills.

\section{REFERENCES}

[1] Horrocks C., Marshall McLuhan and Virtuality, End of Everything Postmodernism \& the Vanishing of the Human, 2000.

[2] Fengfeng Ke, Alicia Fedelina Chávez, Multicultural and Intergenerational Teaching and Learning [M], Current Research, 2013.

[3] Kuang Zhanghong, A study on the Introduction and Reform of Chinese Culture in College English Teaching, Education Modernization, vol. 07, pp. 41-42, 2016.

[4] Runen, B.D., The Study of Cross-cultural Competence: Traditions and Contemporary Issues, International Journal of International Relations, vol. 89, pp.227-229, 2014.

[5] Robert Lado, Ann Arbor, Linguistics across Cultures: Applied Linguistics for Language Teachers, Michigan Press, 1957.

[6] Li Qin and Liu Qin, Research on the Integration of Mother Tongue Culture into Interactive English

Teaching, Anhui Literature, vol. 11, pp. 150-152, 2018.

[7] Kuaibin and He Juan, Reflections on the Communicative Approach in College English Teaching, Course Education Research, vol.37, pp. 96-97, 2016

[8] Wiseman, R. L, Hammer, M. and N. Nishida, Predictors of Intercultural Communication Competence, 
International Journal of Intercultural Relations, vol.37, pp. 349-370, 2014.

[9] Fei Congrong, A Study on the Absence of Chinese Culture in College English Teaching, The Science Education Article Collects, vol. 05, pp. 148-149, 2017. 